\title{
The Effect of Financial Literacy on Financial Behavior Moderated by Information Access
}

\author{
Zuraidah Zuraidah $^{1^{*}}$, Emmi Suryani Nasution ${ }^{2}$ \\ ${ }^{1}$ Ph.D. Student, Department of Management, Faculty of Economics and Business, Universitas Syiah Kuala, \\ Banda Aceh, Indonesia. \\ ${ }^{2}$ Lecturer, Department of Accounting Faculty of Economics, Universitas Muhammadiyah, Banda Aceh, \\ Indonesia. \\ *Corresponding Author: Zuraidah, zuraidah@unmuha.ac.id
}

\begin{abstract}
The purpose of this study was to obtain empirical evidence of the effect of financial literacy on financial behavior moderated by the variable of access to information, in economics faculty students. The phenomenon of this research wanted to detect empirical evidence that students who were wellliterate with the support of access to sufficient information will have good financial behavior. The questionnaire distribution obtained a sample of 42 students of economics. This research used the regression analysis method with moderation. The results of the study indicated that financial literacy had an influence on students' financial behavior which was moderated by information access.
\end{abstract}

Keywords: financial literacy, financial behavior, information access.

\section{Introduction}

Behavioral finance is a theory that examines that there is a psychological effect when an investor makes an investment decision. Financial behavior is seen when someone manages and uses existing financial resources. Individuals who have responsible financial behavior tend to be effective in distributing and using the money they have, conditions that can be seen include making a budget, being able to save money, controlling spending, investing regularly, and paying obligations on time (Nababan \& Sadalia, 2013) in (Sari, 2015).

The decisions and actions are required an understanding that is not only technical but also fundamental. We call this understanding as a financial literacy. According to the Financial Services Authority (OJK), financial literacy is a concept of knowledge, skills, and beliefs that affect attitudes and finances of a person to achieve prosperity. Welfare levels have different measures, but when everyone has a good financial literacy, someone will make good decisions in managing their finances. A survey published by OJK in 2016 recorded Indonesia's financial literacy rate of $29.7 \%$ (https://economy.kompas.com/read/2017/10/04). Financial literacy is usually supported by information access activities because the needs related to the needed information are different for every person.

The behavior finance theory has developed to answer anomalies in traditional financial theory. The assumption of the discussion is that all information in the market will be used by each investor to the maximum to get the most profitable results/benefits, and in the process, each investor will act rationally so that in the end the market will move efficiently. However, when market conditions turn out to be not efficient enough and conditions emerge that are not normal, these conditions are known today as financial behavior. The behavioral finance is a science that studies how humans react and take attitudes to information in their 
efforts to make decisions that can maximize returns by taking into account the risks inherent in them (Jahanzeb \& Saif-ur-Rehman, 2012; Lintner, 1998). Where it can be concluded that the elements of attitudes and actions taken are the determinants in making investment actions.

Research on behavioral finance is a discipline in which there is an inherent interaction of various disciplines and continuously integrates (Ricciardi, 2006). So that the discussion cannot be isolated, financial behavior is built on various assumptions and ideas from economic attitudes/behaviors. The involvement of emotions, traits, preferences and various kinds of things inherent in humans as intellectual and social beings will interact underlies the emergence of decisions in taking an action. Financial behavior indicators used in this study refer to (Sari, 2015) based on research conducted by (Nababan \& Sadalia, 2013) are paying bills on time, recording shopping expenses, providing reserve funds, saving periodically, and comparing prices between stores before buying.

Furthermore, literacy has many definitions expressed by experts, literacy can be interpreted as the ability to read or write. In this context, literacy is defined as the ability to know and understand or it can also be interpreted as the ability that refers to a person's personality to know and understand personal financial management (Sari, 2015). Financial literacy is an understanding concept related to changes in a person's behavior (Garg \& Singh, 2017). Organization for Economic Co-operation and Development, OECD (2016) defined financial literacy as a combination of knowledge and understanding of financial concepts and risks, including the skills, motivation, and confidence to apply them in making effective decisions so that they are beneficial in improving the financial well-being of individuals and society. Garg \& Singh, (2018) also said that the term financial literacy has long been known and used.

Lusardi \& Mitchell (2011) developed a concept of understanding financial literacy as basic financial knowledge and the ability to perform simple calculations. Meanwhile, Mandell \& Klein (2007) in Helen \& Ilias (2019) defined financial literacy as an ability to evaluate new and complex financial instruments that will be used as an assessment for longterm interests. Financial literacy in this study was developed based on research conducted by (Sabri, 2011) the following indicators were used as research questionnaire questions, including purchasing power due to price increases, increase in currency values, effect of savings interest rates, insurance as an investment, credit card ownership, zakat, and emergency fund allocation. The financial literacy affects the financial behavior.

Access can be defined as an opportunity or opportunity to obtain or use certain resources. According to the Ministry of Communication and Information, information access is the convenience provided to individuals or the public to obtain the required public information. Information can be obtained by using tools in the form of telecommunications and through channels or media. Information access needs are recognized as a basic right for everyone. Article $28 \mathrm{~F}$ of the 1945 Constitution states that everyone has the right to communicate and obtain information to develop their personal and social environment, and has the right to seek, obtain, possess, store, manage, and convey information using all available channels. Quality information is information that has the criteria including accurate, timely, relevant, and complete (Hendrick, 2019). Information access strengthens the effect of financial literacy on students' financial behavior.

The purpose of this study was to detect empirical evidence that students who were well-literate with the support of access to sufficient information would have good financial behavior. Based on this, the question of this research was whether the financial literacy variable had an effect on financial behavior which was moderated by the information access variable. 


\section{Method}

\section{Methods of Analysis}

In conducting this research, the author used quantitative methods, based on the philosophy of positivism used in certain populations or samples, data collection used quantitative/statistical research instruments, to test the established hypotheses. The quantitative method was in the form of numbers obtained from measurements using a scale on the variables in the study. The data obtained was then processed into a form of statistical analysis to test hypotheses that explain the relationship between variables. Then tested using Moderated Regression Analysis (MRA) to examine the relationship between the independent variable and the dependent variable which is strengthened or weakened by the presence of a moderating variable (Sugiyono, 2017). The data in this study was quantitative data because the data was measured on a Likert scale. Based on the research data source this was primary data, namely data sourced from respondents obtained directly by using a questionnaire.

\section{Population and Sample}

In this study, the population was economics faculty students who have completed their studies in the second year. The sample was determined based on all completed questionnaires (Umar, 2002). The results of the questionnaire distribution obtained a sample of 42 students of economics. Determination of the sample of this study was used the census method (Arikunto S., 2006).

\section{Data Sources}

The data sources consisted of primary and secondary data. Primary data was the result data collected by the author directly, the primary data source was obtained by distributing questionnaires to the research object and filled directly by the respondents. While secondary data was data obtained through literature study or the results of collecting data or information from literature and references related to research topics (Istijanto, 2010).

\section{Methods and Hypothesis Testing}

The analytical method used was linear regression analysis with moderation to measure financial literacy on financial behavior moderated by access to information. It is formulated as follows:

Note:

$$
\mathrm{Y}=\mathrm{a}+\mathrm{bx}+\mathrm{bz}+\mathrm{bxz}+\mathrm{e}
$$

$\mathrm{Y}=$ Predicted value

$\mathrm{a}=$ Constant

$\mathrm{b}=$ Regression coefficient for $\mathrm{X}$

$\mathrm{z}=$ Moderating variable

$\mathrm{e}=$ Residual value

\section{Results and Discussions}

The first data analysis method carried out was the validity test of Table 1 and the reliability of Table 2 of the research questionnaire were obtained. Based on Table 1, the validity value was measured based on a score of $>0.30$. So that, a valid value was obtained. While in Table 2, reliability was measured based on the alpha level of $>0.60$. So that, a reliable value was obtained. 
Table 1. Validity test

\begin{tabular}{cccc}
\hline Indicator & Variable & $\begin{array}{c}\text { Coefficient } \\
\text { Correlation }\end{array}$ & Description \\
\hline X1.1 & & 0.590 & Valid \\
X1.2 & & 0.575 & Valid \\
X1.3 & Financial & 0.403 & Valid \\
X1.4 & Literacy & 0.516 & Valid \\
X1.5 & & 0.592 & Valid \\
X1.6 & & 0.436 & Valid \\
X1.7 & & 0.490 & Valid \\
Z1.1 & & 0.581 & Valid \\
Z1.2 & Information & 0.515 & Valid \\
Z1.3 & Access & 0.492 & Valid \\
Z1.4 & & 0.634 & Valid \\
Y1.1 & & 0.631 & Valid \\
Y1.2 & Financial & 0.832 & Valid \\
Y1.3 & Behaviour & 0.776 & Valid \\
Y1.4 & & 0.824 & Valid \\
Y1.5 & & 0.433 & Valid \\
\hline
\end{tabular}

Table 2. Reliability test

\begin{tabular}{llcc}
\hline No & \multicolumn{1}{c}{ Variable } & Alpha & Description \\
\hline 1 & Financial Literacy & 0.659 & Reliable \\
2 & Information Access & 0.782 & Reliable \\
3 & Financial Behaviour & 0.681 & Reliable \\
\hline
\end{tabular}

The next test was measured based on the classical assumption test, and it can be interpreted that the data was normally distributed, as seen in Figure 1. The influence of the data to spread up and down can be seen in Figure 2.

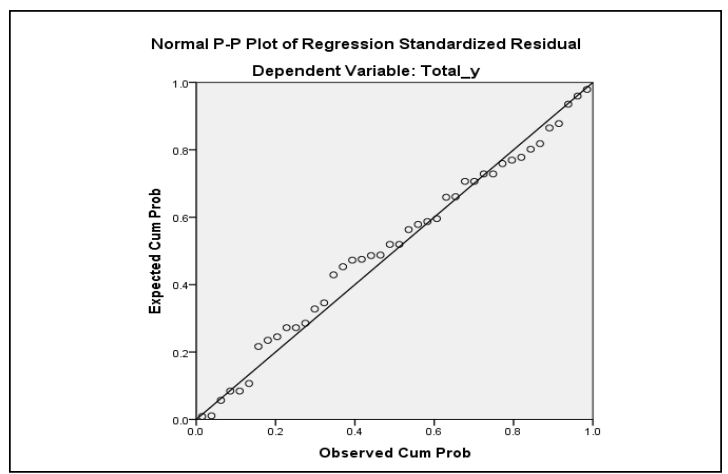

Figure 1. Normal Dependent Variable Test 


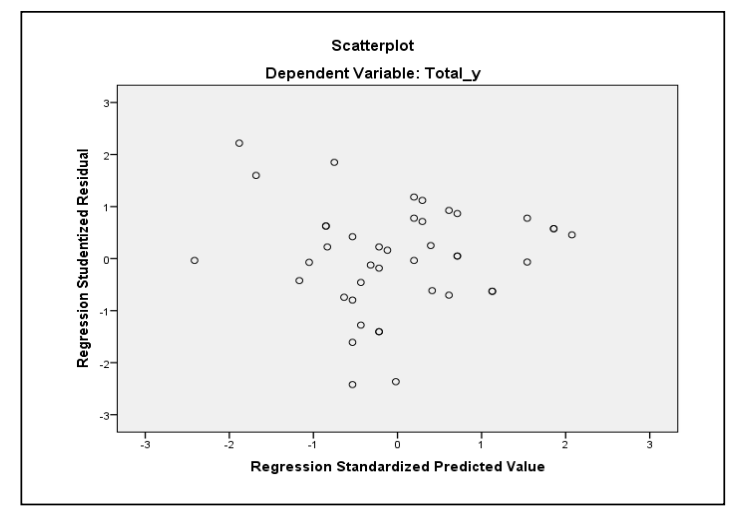

Figure 2. Scatter Plot Dependent Variable test

The multicollinearity test can be seen in Table 3. Table 3 illustrates that there was no multicollinearity of the results obtained. Table 4 shows a significant value of 0.01 , which means that financial literacy affected the financial behavior. Furthermore, Table 5 states that access to information did not have much effect on the financial behavior with a large value of 0.139 .

Table 3. Multicollinearity Test

\begin{tabular}{cclcc}
\hline No & Variable & Tolerance & VIF & Description \\
\hline 1 & $\mathrm{X}$ & 0.999 & 1.001 & Non-Multicollinearity \\
2 & $\mathrm{Z}$ & 0.999 & 1.001 & Non-Multicollinearity \\
\hline
\end{tabular}

Table 4. T-Test of Financial Literacy Variable

\begin{tabular}{|c|c|c|c|c|c|}
\hline \multirow[b]{2}{*}{ Model } & \multicolumn{2}{|c|}{$\begin{array}{l}\text { Unstandardized } \\
\text { Coefficients }\end{array}$} & \multirow{2}{*}{$\begin{array}{c}\begin{array}{l}\text { Standardized } \\
\text { Coefficients }\end{array} \\
\text { Beta }\end{array}$} & \multirow[b]{2}{*}{$\mathbf{t}$} & \multirow[b]{2}{*}{ Sig. } \\
\hline & B & Std. Error & & & \\
\hline (Constant) & 2.683 & 4.802 & & & \\
\hline Total_x & 0.632 & 0.177 & 0.492 & 3.574 & 0.001 \\
\hline
\end{tabular}

Table 5. T-Test of Information Access Variable

\begin{tabular}{cccccc}
\hline & \multicolumn{2}{c}{$\begin{array}{c}\text { Unstandardized } \\
\text { Coefficients }\end{array}$} & $\begin{array}{c}\text { Standardized } \\
\text { Coefficients }\end{array}$ & & \\
\cline { 2 - 4 } Model & $\mathbf{B}$ & Std. Error & Beta & t & Sig. \\
\hline (Constant) & -5.888 & 7.390 & & -0.797 & 0.430 \\
Total_x & 0.638 & 0.174 & 0.497 & 3.667 & 0.001 \\
Total_z & 0.485 & 0.322 & 0.205 & 1.509 & 0.139 \\
\hline
\end{tabular}

Table 6 and Table 7 compare the value of $r$ square to determine the moderating value of the information access variable. It can be concluded that access to information of moderate financial behavior from changes in the value of $r$ square from 0.42 to 0.296 . Means support the second and third hypotheses. 
Table 6. Moderation test

\begin{tabular}{ccccc}
\hline Model & R & $\begin{array}{c}\text { R } \\
\text { Square }\end{array}$ & $\begin{array}{c}\text { Adjusted R } \\
\text { Square }\end{array}$ & $\begin{array}{c}\text { Std. Error of the } \\
\text { Estimate }\end{array}$ \\
\hline 1 & $0.492^{\mathrm{a}}$ & 0.242 & 0.223 & 2.54231 \\
\hline
\end{tabular}

Table 7. Moderation test

\begin{tabular}{ccccc}
\hline Model & R & $\begin{array}{c}\text { R } \\
\text { Square }\end{array}$ & $\begin{array}{c}\text { Adjusted R } \\
\text { Square }\end{array}$ & $\begin{array}{c}\text { Std. Error of the } \\
\text { Estimate }\end{array}$ \\
\hline 1 & $0.544^{\mathrm{a}}$ & 0.296 & 0.240 & 2.51446 \\
\hline
\end{tabular}

\section{Conclusions}

Financial literacy can affect the financial behavior. It was consistent with previous research. The information access modernizes the financial literacy of financial behavior.

\section{References}

Arikunto S. (2006). Prosedur penelitian suatu pendekatan praktik. Jakarta: Rineka Cipta.

Garg, N., \& Singh, S. (2018). Financial literacy among youth. International Journal of Social Economics, 45(1), 173-186.

Helen, T., \& Ilias, S. (2019). Financial Literacy of Graduate High School Students. American Journal of Educational Research, 7(3), 232-236.

Hendrick, T. (2019). Sistem Informasi Manajemen. https://doi.org/10.31227/osf.io/cfy76 Istijanto. (2010). Riset Sumber Daya Manusia, Jakarta: Gramedia Pustaka Utama.

Jahanzeb, A., \& Saif-ur-Rehman. (2012). Implication of Behavioral Finance in Investment Decision-making Process. Information Management and Business Review, 4(10), 532-536.

Lintner, G. (1998). Behavioural Finance: Why Investors make bad Decisions. The Planner, 13(1), 7-8.

Lusardi, A., \& Mitchell, O. S. (2011). Financial literacy and retirement planning in the United States. Journal of Pension Economics and Finance, 10(4), 509-525.

Mandell, L., \& Klein, L. S. (2007). Motivation and financial literacy. Financial Services Review, 16, 105-116.

Nababan, D., \& Sadalia, I. (2013). Analisis Personal Literacy Dan Financial Behavior Mahasiswa Strata 1 Fakultas Ekonomi Universitas Sumatera Utara. Media Informasi Manajemen, 1(1), 1-16.

Ricciardi, V. (2006). A Research Starting Point for the New Scholar: A Unique Perspective of Behavioral Finance, 3(3), 6-23.

Sabri, M. F. (2011). Pathways to financial success: Determinants of financial literacy and financial well-being among young adults. Dissertation. Iowa State University.

Sari, D. A. (2015). Finalcial Literacy Dan Perilaku Keuangan Mahasiswa. Buletin Bisnis \& Manajemen, 01(02), 171-189.

Sugiyono. (2017). Metode Penelitian Kuantitatif, Kualitatif, dan R\&D. Bandung: Alfabeta.

Umar, H. (2002). Metode Riset Bisnis: Panduan Mahasiswa untuk Melaksanakan Riset Dilengkapi Contoh Proposal dan Hasil Riset Bidang Manajemen dan Akuntansi. Jakarta: Gramedia Pustaka Utama. 